\title{
Surgical Indication in Schistosomiasis Mansoni Portal Hypertension - Follow-up from 1985 to 2001
}

\author{
Maria José Conceição/****/+ , Carlos Alberto Argento, Orlando Marques Vieira*, \\ Cristina Maeda Takiya**, Vera Lúcia A Chagas***
}

\begin{abstract}
Serviço de Doenças Infecciosas e Parasitárias, Hospital Universitário Clementino Fraga Filho *Departamento de Cirurgia **Departamento de Histologia e Embriologia ***Serviço de Anatomia Patológica, Instituto de Pediatria e Puericultura Martagão Gesteira, UFRJ, Rio de Janeiro, RJ, Brasil ****Departamento de Medicina Tropical, Instituto Oswaldo Cruz-Fiocruz, Av. Brasil 4365, 21045-900 Rio de Janeiro, RJ, Brasil

The study had the objective to evaluate the benefits of surgical indication for portal hypertension in schistosomiasis patients followed from 1985 to 2001. Schistosoma mansoni eggs were confirmed by at least six stool examinations or rectal biopsy. Clinical examination, abdominal ultrasonography, and digestive endoscopy confirmed the diagnosis of esophageal varices. A hundred and two patients, $61.3 \%$ male (14-53 years old) were studied. Digestive hemorrhage, hypersplenism, left hypochondrial pain, abdominal discomfort, and hypogonadism were, in a decreasing order, the major signs and symptoms determining surgical indication. Among the surgical techniques employed, either splenectomy associated to splenorenal anastomosis or azigoportal desvascularization, esophageal gastric descompression and esophageal sclerosis were used. Follow-up of patients revealed that, independent on the technique utilized, a 9.9\% of death occurred, caused mainly by digestive hemorrhage due to the persistence of posttreatment varices. The authors emphasize the benefits of elective surgical indication allowing a normal active life.
\end{abstract}

Key words: schistosomiasis mansoni - portal hypertension - surgical indication - evolution - esophageal varices

Schistosomiasis mansoni is a widespread parasitic disease which could have about $3 \%$ of hepatosplenic form and 100,000 patients affected by portal hypertension (Kelner 1992). The development and causative factors of the hepatosplenic form were widely discussed by Klöetzel (1964) but remains as an actual theme for discussion. According to Bina (1995), the severe forms are dependent either on the failure of specific treatment and successive reinfections. Moreover, it has been also related to the parasitic load and also to genetic factors from host (Prata 1992, Bina 2001). Interested on the clinical aspects of hepatosplenic form of schistosomiasis mansoni, Coura and colaborators have followed, since 1973, patients from Capitão Andrade, municipality from Vale do Rio Doce, in Minas Gerais, where a ratio of $5.6 \%$ of severe form has been detected (Coura et al. 1992, Conceição \& BorgesBorges-Pereira 2002). Despite the fact that in schistosomiasis the portal hypertension is the main morbid element, the surgical treatment of portal hypertension in schistosomiasis patients has distinct features when compared with cirrhotic patients, mostly because hepatic function is preserved in liver schistosomiasis.

\footnotetext{
${ }^{+}$Corresponding author. Fax: +55-21-2280.3740. Email: conceicao@ioc.fiocruz.br

Received 18 June 2002

Accepted 15 August 2002
}

A total of 102 hepatosplenic patients, aging from 14 to 53 years old, with a male predominance $(61.3 \%)$, coming from Capitão Andrade $(\mathrm{n}=26)$, and from different regions of the country $(n=76)$ as outpatients were derived to the Serviço de Doenças Infecciosas e Parasitárias from the Hospital Universitário, UFRJ, a referal hospital for schistosomiasis. They were examined and submitted to laboratorial examinations: six stool examinations (Kato-Katz method), and when negative, a rectal biopsy. Abdominal ultrasonography, digestive endoscopy, functional hepatic tests and sorology for viral detection (HCB and HCV) were done. The main criteria used for surgical indication were: digestive hemorrhage due to esofageal varices rupture, hypersplenism, pain and abdominal discomfort, and hypogonadism. Patients were submitted to the following surgical procedure: splenectomy associated to splenorenal anastomosis $(\mathrm{n}=39)$, or associated to azigoportal desvascularization $(\mathrm{n}=37)$, esophageal gastric descompression $(n=26)$, and esophageal sclerosis $(n=$ 26). During the surgery fragments of liver and spleen were obtained and processed for histological study. Patients were followed from 1985 to 2001 . The main surgical indications were: digestive hemorrhage caused by rupture of esophageal varices, hypersplenism, pain and abdominal discomfort, and hypogonadism. About $5 \%$ of patients have discontinued the clinical attending, $9.9 \%$ of the patients died because of rebleeding due to the persistence of esophageal varices. There was no significative difference between the surgical procedure employed (ManWhitney test).

Kelner et al. (1982), in an evolutive study (25 years) including 358 schistosomiasis mansoni, hepatosplenic 
patients with a previous digestive hemorrhage observed a death ratio of $11.4 \%$ after rebleeding. However, at this time, sclerotherapy was not employed. The authors did not detected deterioration of the hepatic function. In our cases, we had four patients with a macronodular cirrhosis caused by hepatitis B virus (Conceição et al. 1998). Ferraz (2001) showed a rebleeding rate of $14.4 \%$ and mortality of $5.4 \%$, in a series of patients submitted to splenectomy and division of the left gastric vein, after 30 months of follow-up. The author suggests this type of surgery as the surgical option to the treatment of bleeding due to the rupture of esophageal varices. The benefits of splenectomy were emphasized by Silveira (1980), although its inefficacity when used alone has been shown (Raia et al. 1985). The same risk of rebleeding was encountered when comparing the ligature of esophageal varices alone with patients submitted to a splenorenal anastomosis (Kelner 1992).

Our study emphasize that regardless of the surgical procedure, the same rate of death occurs as a consequence of rupture of esophageal varices. And further that, our death rate is similar to the majority of series described.

\section{REFERENCES}

Bina JC1995. Estudo das Variáveis que Podem Influenciar na Evolução da Esquistossomose Mansônica. Efeito da Terapêutica Específica e da Interrupção da Transmissão, $\mathrm{PhD}$ Thesis, Universidade Federal da Bahia, Salvador, 126 pp.

Bina JC 2001. Study of variables that may influence in the evolution of the hepatosplenic form of schistosomiasis mansoni. Abstracts Book on 8th International Symposium on Schistosomiasis. Miniconference 2, p. 6.
Conceição MJ, Borges-Pereira J 2002. Influence of specific treatment on the morbidity of schistosomiasis mansoni in an endemic area of Minas Gerais, Brazil. Mem Inst Oswaldo Cruz 97 (Suppl. I): 755-757.

Conceição MJ, Argento CA, Chagas VLA, Takiya CM, Silva DC, Figueiredo SC 1998. Prognosis of schistosomiasis mansoni patients infected with hepatitis B virus. Mem Inst Oswaldo Cruz 93: 255-258.

Coura JR, Conceição MJ, Santos ML, Mendonça ZG, Cutrim RNM 1992. Cross-seccional and evolutive studies of schistosomiasis mansoni in untreated and mass treated endemic areas in the Southeast and Northeast of Brazil. Mem Inst Oswaldo Cruz 87 (Suppl. IV): 75-82.

Ferraz AAB 2001. Portal hypertension in schistosomiasis Surgical treatment of schistosomiasis portal hypertension. Abstracts Book on 8th International Symposium on Schistosomiasis. Round Table 9, p.27.

Kelner S 1992. Critical evaluation of surgical treatment of schistosomotic portal hypertension. Mem Inst Oswaldo Cruz 87 (Suppl. IV): 357-368.

Kelner S, Ferreira PR, Dantas A, Lima Fo JC, Souza AP, Carreiro Jr JCP, Ferraz EM, Silveira M, Coelho ARB, Câmara Neto RS, Domingues LA 1982. Ligadura de varizes esôfagogástricas na hipertensão porta esquistossomótica. Avaliação de 25 anos. Rev Col Bras Cir 9: 140-146.

Klöetzel K 1964. Natural history and prognosis of splenomegaly in schistosomiasis mansoni. Am J Trop Med Hyg 13: 541-544.

Prata A 1992. Influence of the host related factors in the development of the hepatosplenic form in schistosomiasis mansoni. Mem Inst Oswaldo Cruz 87 (Suppl. IV): 39-44.

Raia S, Miess S, Macedo AL 1985. Portal hypertension in schistosomiasis. Clin Gastroenterol 14: 57-82.

Silveira GM 1980. Circulações Arterial e Portal do Fígado Esquistossomótico após Esplenectomia, Thesis, UFBa, Salvador, $151 \mathrm{pp}$. 